\title{
The Current State of Deregulation of Space Activities in Ukraine
}

\author{
Vasyl Semenyaka \\ $\mathrm{PhD}$ of law, Senior Researcher at the Institute of State and Law named after V. M. Koretsky \\ NAS of Ukraine (Kiev, Ukraine) \\ E-mail: v.semenyaka@ukr.net \\ https://orcid.org/0000-0002-1621-9694
}

\begin{abstract}
In this article, the theoretical and practical legal aspects of deregulation of national space activities are analyzed. It is established that the norms of international space law do not provide for a specific authorization mechanism for space activities in outer space. It is proved that its implementation should be carried out by States at the level of national space legislation. The main stages of development of the legislation of Ukraine on licensing of space activity are shown. The purpose of this paper is to justify the cancellation of licensing of space activities in Ukraine, as well as non-compliance with the basic principles of expediency and adequacy of the state regulatory policy of legislative initiatives on the resumption of the licensing procedure for space activities.
\end{abstract}

Keywords: deregulation, space activities, international space law, licensing, certification

Received: January 10, 2019; accepted: February 11, 2019

Advanced Space Law, Volume 3, 2019: 108-119.

https://doi.org/10.29202/asl/2019/3/9

\section{Introduction}

One of the main elements of state and legal policy in the sphere of the national economy in recent years is the organization and conduct of deregulation (deregulation) of economic activities in certain areas of public relations - the elimination of administrative barriers to the effective implementation of business. The implementation of the tasks of administrative and legal reform of state regulation resulted in a significant reduction in 2015, in particular, licensed types of economic activities [Zakon, 2015].

At the same time, due to the implementation of the process of deregulation of radical changes, the legal regulation of the conditions for the conduct of national space activities has undergone. Thus, the list of licensed types of management in Ukraine excludes activities related to the development, testing, production, operation of launch vehicles, spacecraft and their components, ground control complex of spacecraft and its components. Since then, the implementation of the right to carry out space activities in Ukraine does not require a business entity to obtain a license document.

(C) Semenyaka, Vasyl, 2019 
However, recently, the legislative work of the Central Executive body in the field of space activities (hereinafter - the SCA of Ukraine) has intensified in the direction of restoring the licensing procedure for the implementation of national space activities [Proekt, 2019].

In the light of the legislative initiatives, scientific and practical studies of the legal prerequisites (bases) for the adequacy and appropriateness of the licensing procedure for space activities are extremely relevant, since the state has a special mission in ensuring the sustainable development of national space activities. It is at the legislative level that the basic principles, norms and rules of space activities should be established.

The purpose of the article is a theoretical study of international and national legal principles of the licensing mechanism of space activities, legal assessment and analysis of the implementation of measures taken to reduce government intervention in the field of space activities.

\section{Presentation of the main material}

According to the international commitments Ukraine as a part to the Treaty on principles governing the activities of States in the exploration and use of outer space, including the moon and other celestial bodies (hereinafter the outer space Treaty) shall bear international responsibility for national activities in outer space, including the moon and other celestial bodies, regardless of whether it is governmental bodies or non-governmental legal entities, and for assuring that national activities are carried out in accordance with the provisions contained in this Agreement (paragraph 1 of article VI of the outer space Treaty) [Dohovir, 1966]. States have an obligation to take appropriate measures to ensure that persons engaged in space activities carry out them in accordance with international law. However, Article II of the Convention on international liability for damage caused by space objects provides that the launching state is absolutely responsible for compensation for damage caused by its space object on the surface of the Earth or to an aircraft in flight [Konventsiya, 1971].

However, article VI of the outer space Treaty provides that the activities of non-governmental legal persons in outer space, including the moon and other celestial bodies, shall be carried out with the permission and under the constant supervision of the state party Concerned. This means that the activities of non-governmental legal persons must be continuously monitored by the state in order to ensure their implementation in compliance with the relevant norms and principles of international space law.

These provisions of international space law give rise to the following legal consequences: (1) a state shall be internationally consistent for national space activities; (2) a state shall ensure that national space activities comply with the norms and principles of international space law; and (3) a state shall establish a permissive procedure for activities in outer space, including the moon and other celestial bodies.

It should be noted that in order to understand the present international legal content of the permissive condition of the outer space Treaty and to ensure its correct application, it is important to determine the place of space activities: the territory of the Earth or outer space, since the permissive regime, based on the literal content of the provision of article VI of the outer space Treaty, is applicable to activities that are carried out in outer space and on celestial bodies. Therefore, the characteristics of international responsibility for national space activities are determined depending on the place of their implementation. 
However, the rule of article VI of the outer space Treaty does not define specific activities in outer space and on celestial bodies that require a permissive legal regime of production and does not specify the types and forms of authorization (supervision). In other words, the rule does not provide for a specific national legal regime to be adopted by States with a view to granting such authorization, nor does it provide for international legal provisions on how States should fulfil their obligations with regard to permanent monitoring.

The legal procedure for the introduction of a licensing mechanism for national space activities is that, on the basis of article VI of the outer space Treaty, each state independently determines in national legislation specific types of space activities that require appropriate licensing regulation. Scilicet, States have the discretion to decide which space activities should be "authorized" to ensure that a state fulfils its international space obligations.

The analyzed provisions of the first and second sentence of part 1 of article VI of the outer space Treaty on the control and supervision of national space activities should be applied in the system of legal communication. Their respective interpretation makes it possible to conclude that the licensing mechanism for the production of space activities is introduced in order to ensure compliance of national space activities with the norms and principles of international space law, as well as the assignment of responsibility. Therefore, the licensing mechanism for the implementation of space activities is not an end in itself, but one of the legal instruments to ensure the implementation of international space obligations.

On the other hand, the relevant rule is not self-sufficient in international space law, since it does not create a direct international legal obligation of the state to grant permission for the implementation of space activities, the implementation of permanent control (supervision). In other words, the legal norm does not automatically generate legal consequences in the form of the use of the authorization mechanism of national space activities.

This rule belongs to the category of international legal requirements, the legal effect of which requires the adoption of a special act of national legislation, if States by other legal means cannot control this activity. That is, the introduction of a licensing mechanism and the definition of the relevant activities in outer space - granting the right to their production should be carried out by States at the level of national space legislation. This means that in order to ensure the implementation of these norms of international space law, there is an objective need for States to form and develop national space law.

States independently develop acts of national space legislation, establishing specific legal bases for the implementation of international obligations of States, and introducing requirements for the implementation of space activities. At the same time, States have the right to apply any instrument of state regulation that they deem appropriate and that is consistent with their national interests and policies, taking into account the space commitments undertaken. But before its introduction, there is international legal uncertainty about the specific authorization mechanism for space activities. In this regard, the United Nations General Assembly (hereinafter referred to as the UNGA) recommends that States engaged in space activities, in fulfilling their international obligations under the United Nations treaties on outer space, consider adopting and implementing national laws providing for the issuance of permits for the activities of non-governmental entities under their jurisdiction in outer space and for the ongoing supervision of those activities [Rezolyutsyya 59/115, 2005]. Now the relevant UNGA resolution document belongs to the category of "soft law" acts (soft law).

Thus, by their legal nature, the norms of the outer space Treaty on the permissive order of space activities are of a discretionary nature. Their content does not imply the obligation of 
States to introduce exclusively licensing procedures for the implementation of space activities, since the implementation of international space obligations can be provided by States in a variety of national legal ways.

The fundamental legal principles of the implementation of space activities in Ukraine are the state regulation of space relations, the evolution of development and the consistency of the reform of the state policy in the field of research and use of outer space. To ensure the implementation of the national space policy, the state uses a variety of means and mechanisms of state regulation of economic (space) activities. Now the influence of the state should be directed to the achievement of specific goals.

The formation and development of modern entrepreneurship in the field of research and use of outer space should be based on the free choice of economic entities of the types of production of national space activities. And the boundaries of freedom of enterprise should be determined by the specific conditions of space activities. Therefore, the task of the state, which requires an adequate solution, is the legal consolidation of the most favorable and equal conditions for the implementation of national space activities by subjects using legally balanced modern methods and means of state regulation.

The initial legal basis for the state regulation of space activities is the legal principle of its scientific validity, which involves taking into account these norms and principles of international space law, as well as the peculiarities of licensing and space legislation, the state of development of national space activities, etc.

State regulation of space activities is unquestionably effective when its permissible limits are determined by the specific conditions of the space market. Government regulation is generally recognized as necessary if the market-based self-regulation mechanism is unable to meet the challenges of sustainable space activities. Of these objective reasons, it is supplemented by effective administrative and legal means of regulating the influence of the state on the activities of economic entities (licensing, patenting, technical regulation, etc.). At the same time, the most optimal combination of market self-regulation of space relations between economic entities and state regulation is extremely important, since it is their interaction and coexistence that is the key to the efficiency and further development of space activities.

The Constitution of Ukraine and the law in the interests of the state and society may establish certain restrictions on the implementation of space activities-restriction of freedom of space activities, which predetermines the narrowing of the content and scope of the rights of its subjects to business activities. It is important to note that the introduction of legal restrictions is legitimate if it is carried out solely for the purpose of national security, defense and other public interests. That is, the freedom of entrepreneurship, as an exception, is legally limited to guarantee public interests.

A systematic analysis of the national space legislation indicates the consolidation of special types of legal restrictions in the implementation of space activities in Ukraine. The first type of restrictions is restrictions on the right to carry out space activities on the subject composition of participants in space legal relations. According to the definition of article 1 of the Law of Ukraine "On space activities", enterprises, institutions and organizations, including international and foreign ones, which carry out space activities are recognized as subjects of space activities in Ukraine [Zakon, 1996]. As we can see, individuals are not classified as subjects of national space activities. Thus, the subject structure of participants of space activity in Ukraine is the corresponding limited circle of economic entities. Along the way, it should be noted that there are no necessary legal prerequisites for the functioning of this legislative 
restriction of freedom, of space entrepreneurship, since the recognition and implementation of national space activities by individuals does not pose any threat to the national security of Ukraine and the like.

At the same time, the state has fixed a restriction on persons who can act as participants in real legal relations, the subject of which are rocket and space systems, provided for by the Verkhovna Rada of Ukraine from 17.06.1992. "On the right of ownership of certain types of property" [Postanova, 1992]. Military rocket and space complexes have a special national legal regime, the peculiarity of which is that they belong to things that are limited in civil turnover: these rocket and space complexes cannot be owned by citizens, public associations, international organizations and legal entities of other States on the territory of Ukraine.

The second type of restrictions is the restriction of the right to entrepreneurship by types of space activities and organizational and legal forms of management. The dispositive norm of part 4 of article 22 of the Economic code of Ukraine provides that the law can define types of economic activity which are allowed to be carried out only to the state enterprises, organizations and the organizations [Hospodars'kyy kodeks, 2003]. The peculiarities of the production of certain types of space activities are determined by the fact that the prerogative of exclusively state enterprises and organizations is to carry out activities related to the development, testing, production and operation of launch vehicles, including their space launches for any purpose [Zakon, 1997]. Others - "non-state" business entities are still not entitled to engage in the relevant type of space activities in Ukraine.

These types of national space activities are now virtually monopolized by the state. Now a full-fledged economic activity related to the direct creation and use of launch vehicles, as evidenced by space practice, is carried out by two main economic entities of the public sector, which are based on state ownership and are in the control of the state enterprise of Ukraine: state enterprises "Production Association" southern machine-building plant. O. M. Makarov" and "Design Bureau "Pivdenne" to them. V. V. Makarova. M. K. Yangel" These enterprises of the rocket and space industry are state-owned objects of strategic importance for the economy and security of the state [Postanova, 2010] and enjoy the exclusive right to carry out the above-mentioned type of space activity on the territory and under the jurisdiction of Ukraine. But other entities of the space industry are involved only in the process of manufacturing components, components of rocket and space technology.

It is important to note that the state has the right to have a decisive influence on the economic activities of the relevant entities of the space industry, determines the conditions for their individual economic activities or aspects of activities, thus the state exercises total control and supervision over their activities. It is obvious that the legislative consolidation of the corresponding exclusive right to the implementation of the analyzed type of space activity is aimed at ensuring the implementation of space activities, which guarantees the state the opportunity to promote the safe implementation of such activities, while remaining fully responsible for such activities.

At the same time, it should be noted that there is a special legal regime for the movement across the customs border of Ukraine of dual-use goods that can be used for military or terrorist purposes or for the development, production, use of military goods, weapons of mass destruction, means of delivery of these weapons or nuclear explosive devices [Postanova, 2004]. Such things include, in particular, certain space launch vehicles, spacecraft, space platforms, spacecraft payloads, on-Board systems and on-Board spacecraft equipment and 
ground equipment. Therefore, objects of space technology that can be used in the creation of conventional weapons, military or special equipment are subject to special state control.

At the same time, the modern space legislation of Ukraine provides for a permissive mechanism for the implementation of foreign economic space activities, which covers activities in outer space and on celestial bodies. By the way, the domestic practice of control and supervision of national space activities has no analogues in the world space practice. Its peculiarity lies in the fact that the subjects of space activity of Ukraine provides for the procedure for obtaining permission to conduct negotiations with foreign entities on issues of exploration and use of outer space, production and exploitation of space technologies, implementation expert, import and reexport of space equipment and space technologies, their temporary export outside Ukraine or temporary importation into its territory, transit of the territory of Ukraine (article 11-1 of the law of Ukraine "On space activities"). Obtaining the appropriate permits by the subjects of space activities of Ukraine for the implementation of foreign economic activity is mandatory. The result of the negotiations is the conclusion of agreements (agreements, contracts, etc.) with a foreign business entity on the exploration and use of outer space, production and operation of space technology, purchase and sale of space technology. The specified contracts (contracts) the subject of space activity submits to SSA of Ukraine for carrying out registration.

In turn, the SCA of Ukraine carries out the examination of the submitted agreement for compliance with the legislation, takes measures for the legal protection of intellectual property objects, protection of state interests in addressing the use of objects created in the space industry at the expense of budgetary funds. According to the results of the examination, the SCA of Ukraine registers these agreements (contracts) of the subjects of space activity of Ukraine with foreign subjects of space activity, or makes decisions on refusal of registration [Postanova, 1998].

On the basis of the contracts (contracts) registered in SSA of Ukraine, objects of space activity (space equipment) are developed, made and operated according to requirements of the tactical and technical task (technical task), specifications and operational and technical documentation by definition of the General customer (customer) and the consumer of space services [Postanova, 2001]. Thus for ensuring development, production and operation of objects of space activity subjects of space activity shall be metrologically certified material and technical means and technologies, normative and technical documentation and documentary confirmation of certification of the workers serving these objects.

In fact, this legal instrument of state regulation of foreign economic space activities belongs to the system of licensing procedures for the implementation of national activities in outer space, including the moon and other celestial bodies, since it is excluded, according to the study and use of outer space, the production and operation of space technology, the purchase and sale of space technology and technology without compliance with the procedure for obtaining a permit for negotiations and registration of relevant transactions.

A special group of restrictions on economic activities in the field of the creation and use of space technology should include a ban on certain types of space activities without a special permit (license). Implementation of economic activities required a special permit - the legal consent of the state to engage in certain economic entities certain types of space activities. It was the license that was the basis for the emergence of a person's special legal capacity, which determined the ability to engage in a certain type of space activity.

The introduction of licensing of space activities was the most common administrative and legal means of regulating the influence of the state on the activities of economic entities 
in the field of space activities. Licensing was a special prerequisite for the implementation of enterprises, institutions and organizations of economic (space) activities in Ukraine, since the license was recognized as the only document of a permissive nature, which granted the right to a business entity to engage in a certain type of space activity, in accordance with the law was subject to restriction (licensing). Licensing was carried out for the purpose of state control in the space industry of Ukraine, improving the quality and competitiveness of space technology products, its components and space services, as well as ensuring the safety of production and environmental protection. In other words, special state control over certain types of space activities has been established through the use of a licensing mechanism for space activities.

Historical and legal analysis of the main stages of the formation of the legislation of Ukraine on space activities shows that the administrative and legal Institute of licensing has always been an integral part of the national space activities. As a result of the establishment and development of certain activities related to the exploration and use of outer space, the state introduced their licensing: granted permission for the right to carry out space activities and established special control over its implementation. Therefore, the state controlled all national space activities.

It should be noted that the licensing procedure for the implementation of space activities was first introduced into the Ukrainian space legal field by the Cabinet of Ministers of Ukraine in 1996 in order to ensure the interests of the state in the process of research and use of outer space, production and operation of space technology [Postanova, 1996]. They secured the obligation to issue certificates to business entities on the right to carry out the following types of space activities:

1) scientific research and use of outer space;

2) development of space technology and ground infrastructure;

3) production of space technology;

4) repair of space technology;

5) modernization of space technology;

6) receipt and use of information from space vehicles;

7) creation of space technology;

8) provision of space services;

9) purchase and sale of space technology.

At the beginning of the stage of formation of the national space, as we can see, the state planned to exercise total control over the types of space activities.

In 1996, with the adoption of the special Law of Ukraine "On space activities", the licensing instrument for the production of space activities was modernized. Since then, according to article 10 of this Law, any subjects of space activities that carry out or intend to carry out this activity in Ukraine and under the jurisdiction of Ukraine outside its borders must obtain a license from the Central Executive body that implements the state policy in the field of space activities (SSA of Ukraine) to carry out this activity. At the same time, it is determined that the list of space activities subject to licensing is determined by law.

With the adoption of this Law and the imposition of restrictions in the implementation of certain types of entrepreneurial activity established a new list of the types of space activities that cannot be carried out without a license, namely:

1) research related to the creation and use of space equipment and technologies (except rockets); 
2) development, testing, manufacture and operation of spacecraft and their component parts, ground infrastructure and its components, equipment that is part of space segment of satellite systems, with the exception of television and radio broadcasting systems;

3 ) the transfer, receipt, the dissemination and use of data of space objects, except the questions carried to the competence of the National Council on television and radio broadcasting;

4) the provision of satellite services relating to:

a) lease resources from national and international systems of satellite communication and broadcasting operators and users;

b) warranty service and supervision for space technology;

c) implementation of space equipment and technology [Postanova, 1998a].

As we can see, the creation and use of launch vehicles are excluded from the list of licensed types of space activities. This is explained by the fact that the implementation of the abovementioned type of business was assigned to a specially defined range of subjects of space activities - state enterprises and organizations.

A certain weakening (decrease) in the volume of state regulation of space activities began in 2000 by stopping the licensing of certain types of space activities. Since then, in connection with the improvement of the licensing mechanism of economic activity, the provisions of the Law of Ukraine "On licensing of economic activities" stopped licensing of certain types of space activities. Paragraph 22 of article 9 of this Law provided for licensing only the development, testing, production, operation of launch vehicles, spacecraft and their components, ground space infrastructure and its components, equipment that is part of the space segment of satellite systems [Zakon, 2000]. Business entities of the space industry were "exempted" from compliance with the licensing procedure for the right to carry out other types of space activities. However, in the list of licensed types of space activities, the licensing of activities for the development, testing, production and operation of launch vehicles, the implementation of which is the exclusive right of state enterprises and organizations, has been renewed.

In 2009, this paragraph of the Law on licensing underwent editorial clarification: licensing was subject to separate development, testing, production, operation of launch vehicles, spacecraft and their components, ground control complex of spacecraft and its components [Zakon, 2009]. At the same time, the creation and use of equipment that is part of the space segment of satellite systems are excluded from the list of licensed types of space activities.

The analysis of the main stages of formation of the legal Institute of licensing in the field of space activities showed a gradual reduction in the number of licensed its types, up to the complete abolition of licensing of space activities. Since 2015, the subjects of national space activities have acquired the right to carry out any type of space activity without a license on the basis of their free choice.

The reform in terms of deregulation of economic activities is aimed at reducing the regulatory burden, simplifying and improving the conditions for the production of space activities. Consequently, by eliminating the excessive regulation of space activities, there is a reduction of the relevant state regulation and the creation of a modern legislative framework in accordance with the market mechanisms of management.

Article 4 of the Law of Ukraine "On entrepreneurship" concerning the exclusive right of space enterprises of the public sector of the economy to carry out activities related to the development, testing, production and operation of launch vehicles and their space launches is also awaiting changes. The state should allow for the implementation of this type of activity 
of subjects of other forms of ownership, eliminating a clearly discriminatory approach to business entities.

I am convinced that deregulation of space activities in Ukraine will contribute to the further development of national space activities, improvement of legislation in the field of research and use of outer space, including the moon and other celestial bodies, stimulate entrepreneurship and ensure a balance between the interests of business and the state.

The basic legislative principle of the state policy in the field of licensing is the priority of protection of rights, legitimate interests, human life and health, the environment, protection of limited resources of the state and ensuring the security of the state. Its implementation consists in the fact that the licensing of economic activities is applied only to such type of activity, the implementation of which poses a threat of violation of the rights, legitimate interests of citizens, human life or health, the environment and/or security of the state, and only in case of insufficiency of other means of state regulation.

Consequently, the need for licensing in the field of space activities should be determined on the basis of the degree of risk of a particular type of space activity to ensure the safety of the population, the environment and the state. In other words, licensing is introduced in respect of those types of economic activities, the implementation of which constitutes a threat and danger. These circumstances are the basic (initial) legal principles, guidelines, which are based on the development and implementation of modern tools of state influence on certain types of social relations in the field of space activities.

In this regard, it is important to determine the urgent need for appropriate state intervention in the sphere of national space activities through the introduction of the legal Institute for licensing space activities. The solution of this problem necessitates the analysis of specific circumstances that determine the need to restore the permissive order of space activities, as well as the identification and evaluation of alternative ways to achieve the objectives of state regulation of space activities (for example, licensing instruments, certification, mandatory space insurance).

The purpose of state regulation of licensing of space activities is to establish state supervision over the safety of space activities, public safety and environmental protection.

A special place in the regulation of relations in the field of space activities is given to the rules of space activities in Ukraine, are by-laws, which are carried out regulatory and legal support of space activities. These include norms of operational suitability of space activities, standards and normative documents, which regulate the procedure, in particular, certification of space technology; organization, implementation and maintenance of space launches and flights; supervision and control over the safety of space launches and flights and operation of space technology; environmental protection in the process of space activities. At the same time, the rules of space activities are binding on all subjects of space activities (enterprises, institutions and organizations engaged in space activities).

Any object of space activity in Ukraine is subject to certification for compliance with the requirements of operational suitability established by the normative documents in force in Ukraine, with registration of the certificate of conformity (article 12 of the Law of Ukraine "On space activity"). It is a question of compliance of object of space activity to requirements of operational suitability of space equipment regulated by the regulatory documents operating in Ukraine.

Part 1 of article 11 of the Law of Ukraine "On technical regulations and conformity assessment" provides that compliance of the products put into circulation, provided on the 
market or put into operation in Ukraine with the requirements of all applicable technical regulations that apply to such products is mandatory [Zakon, 2015]. At the same time, compliance of products with the requirements of technical regulations can be ensured through the application of national standards and/or technical specifications referred to in the relevant technical regulations. The technical regulations specify that compliance of products with such national standards and/or technical specifications is the only way, one of the ways to meet the relevant requirements of the technical regulations.

At the same time, article 15 of the Law of Ukraine "On space activities" provides that the object of space activities is allowed to operate if it has a certificate of conformity. That is, a document that certifies the compliance of the object of space activity with the requirements of the operational suitability of space technology, regulated by regulatory documents in force in Ukraine.

Thus, Ukraine has a multi-stage system of state supervision (control) over national space activities: space activities should be checked for compliance, certification, state control and expertise of the state space Agency of Ukraine in the implementation of foreign economic relations.

Meanwhile, state intervention in space activities should be minimal and legally balanced. Licensing of space activities should be introduced when the subjects of national space activities cannot independently ensure the safety and quality of space products (goods, works, services), compliance of their national space activities with the norms and principles of international space law. At the same time, the licensing and licensing procedure for space activities should not be applied to national space activities, the safety of which is ensured, for example, by the design of spacecraft or launch vehicles.

In the context of the above, the use of soft modern forms of state regulation of space activities, tested by practice, seems to be effective. An alternative to the use of the Institute of licensing can be, in particular, the increase in requirements for the quality of space products, the introduction of certification of certain types of space activities, compulsory insurance of space risks [Semenyaka, 2007: 240].

It is important to note that certification in the field of space activities is aimed at confirming the quality of space products, which allows to increase its competitiveness, as well as to protect the interests of third parties (consumers). At the same time, the quality management certification is a measure of the national legal instrument that ensures the production of highquality space products at all stages of the technological cycle by the Ukrainian rocket and space enterprises, which contributes to the active promotion of space services and technologies in the market.

It is established that the functioning quality management system of the leading Ukrainian space enterprises: State Enterprise "Production Association Southern machine-building plant named after O. M. Makarov" on production, testing and operation of production of space equipment conforms to the state and international requirements of State Standard of Ukraine ISO 9001-2001 [ISO, 2001], and State Enterprise "Design Bureau "Pivdenne" — to requirements of State Standard of Ukraine ISO 9001: 2015" quality management System. Requirements" for the production, testing and operation of rocket and space technology products, etc. [Systema, 2018].

Thus, effective market mechanisms and instruments of self-regulation in the implementation of national space activities ensure the safety of space products for an unlimited number of persons, thereby guaranteeing the security of the state in the field of international space 
relations. Activities in the exploration and use of outer space should not be licensed if an effective legal certification mechanism is in place.

\section{Conclusions}

1. The study of the formation and development of the licensing procedure for the implementation of space activities in Ukraine testified to the existence of an integrated system and tools of state supervision (control) of national space activities.

2. At the present stage of the development of national space activities, the abolition of its licensing is balanced and legally justified, since the licensing procedure for space activities does not contribute to the creation of attractive economic and legal conditions for the development of activities in the field of research and use of outer space. It is obvious that the legal Institute for licensing space activities actually restricts access to the market of space services and technologies, since the possibility of launching space activities is procedurally complicated. Extremely complex administrative and legal procedures for the acquisition of the right to carry out space activities limit, first of all, the desire of business entities to deal with this risk.

3. Legislative initiatives to renew the licensing of space activities do not comply with the basic principles of expediency and adequacy of the state regulatory policy defined by the Law of Ukraine "On the basis of the state regulatory policy in the sphere of economic activity". The introduction of the licensing and licensing procedure for space activities will not contribute to the creation of attractive economic and legal conditions for the development of national space activities, but will lead to excessive regulatory influence of the state on this sphere of management.

\section{References}

Dohovir pro pryntsypy diyal'nosti derzhav po doslidzhennyu i vykorystannyu kosmichnoho prostoru, vklyuchayuchy Misyats' ta inshi nebesni tila vid 19.12.1966 r. https://zakon. rada.gov.ua/laws/show/995_480

Hospodars'kyy kodeks Ukrayiny vid 16.01.2003 r. Vidomosti Verkhovnoyi Rady Ukrayiny. № 18, № 19-20, № 21-22 — St.144, 2003.Zakon Ukrayiny. Pro litsenzuvannya vydiv hospodars'koyi diyal'nosti: vid 03.03.2015 r. Vidomosti Verkhovnoyi Rady Ukrayiny. № 23. - St. 158., 2015.

ISO 9004:2001 Quality management systems — Guidelines for performance improvements. 2001. https://www.zoda.gov.ua/files/WP_Article_File/original/000011/11933.pdf

Konventsiya pro mizhnarodnu vidpovidal'nist' za shkodu, zavdanu kosmichnymy ob"yektamy vid 29.11.1971 r. https://zakon.rada.gov.ua/laws/show/995_126

Postanova Verkhovnoyi Rady Ukrayiny. Pro pravo vlasnosti na okremi vydy mayna: vid 17.06.1992 r. № 2471-XII. Vidomosti Verkhovnoyi Rady Ukrayiny. № 35. - St. 517, 1992.

Postanova Kabinetu Ministriv Ukrayiny. Pro zatverdzhennya Polozhennya pro poryadok vydachi sertyfikativ na pravo zdiysnennya kosmichnoyi diyal'nosti subyektamy pidpryyemnyts'koyi diyal'nosti Ukrayiny ta pro rozmir i poryadok styahnennya platy za vydachu sertyfikata na pravo zdiysnennya kosmichnoyi diyal'nosti: vid 01.04.1996 r. № 376. https://zakon.rada.gov.ua/laws/show/376-96-\%D0\%BF 
Postanova Kabinetu Ministriv Ukrayiny. Pro zatverdzhennya Polozhennya pro poryadok nadannya dozvoliv sub'yektam kosmichnoyi diyal'nosti na provedennya perehovoriv z inozemnymy sub'yektamy hospodars'koyi diyal'nosti shchodo doslidzhennya i vykorystannya kosmichnoho prostoru, vyrobnytstva i ekspluatatsiyi kosmichnoyi tekhniky ta ukladennya dohovoriv kupivli-prodazhu kosmichnoyi tekhniky i tekhnolohiy, reyestratsiyi dohovoriv, predmetom yakykh ye kosmichna diyal'nist', ukladenykh sub'yektamy pidpryyemnyts'koyi diyal'nosti Ukrayiny z inozemnymy sub’yektamy hospodars'koyi diyal'nosti: vid 04.06.1998 r. № 798. Ofitsiynyy visnyk Ukrayiny. № 22. - St. 810, 1998.

Postanova Kabinetu Ministriv Ukrayiny. Pro zatverdzhennya Poryadku vydachi litsenziy sub"yektam pidpryyemnyts'koyi diyal'nosti na pravo zdiysnennya kosmichnoyi diyal'nosti: vid 04.06.1998 r. № 798a. https://zakon.rada.gov.ua/laws/show/798-98$\% \mathrm{D} 0 \% \mathrm{BF}$

Postanova Kabinetu Ministriv Ukrayiny. Pro zabezpechennya vykonannya Zakonu Ukrayiny "Pro derzhavnu pidtrymku kosmichnoyi diyal'nosti”: vid 07.02.2001 r. № 131. Vidomosti Verkhovnoyi Rady Ukrayiny. 2000.

Postanova Kabinetu Ministriv Ukrayiny. Pro zatverdzhennya Poryadku zdiysnennya derzhavnoho kontrolyu za mizhnarodnymy peredachamy tovariv podviynoho vykorystannya: vid 28.01.2004 r. № 86. Ofitsiynyy visnyk Ukrayiny. № 4. - tom 1. St. 167, 2004.

Postanova Kabinetu Ministriv Ukrayiny. Pro vyznachennya kryteriyiv vidnesennya obyektiv derzhavnoyi vlasnosti do takykh, shcho mayut' stratehichne znachennya dlya ekonomiky i bezpeky derzhavy: vid 03.11.2010 r. № 999. Ofitsiynyy visnyk Ukrayiny. № 84. - St. 2948, 2010.

Proekt Zakonu Ukrayiny. Pro vnesennya zmin do Zakonu Ukrayiny "Pro litsenzuvannya vydiv hospodars'koyi diyal'nosti”: vid 06.12.2017 r. http://www.drs.gov.ua/wpcontent/uploads/2017/12/13836_06_12_2017.pdf; Pro vnesennya zmin do deyakykh Zakoniv Ukrayiny shchodo demonopolizatsiyi ta rozvytku kosmichnoyi diyal'nosti: proekt Zakonu Ukrayiny vid 27.02.2019 r. http://w1.c1.rada.gov.ua/pls/zweb2/ webproc4_1?pf3511=65569

Rezolyutsyya 59/115 HA OON. Prymenenye kontseptsyy „,zapuskayushchee hosudarstvo”: vid 25.01.2005. http://www.unoosa.org/pdf/gares/ARES_59_115R.pdf

Semenyaka, Vasyl. Strakhuvannya u sferi kosmichnoyi diyal'nosti: teoretyko-pravovi zasady. - K. VD "Akademperiodyka”, 2008.

Systema menedzhmentu yakosti, 2018 // https://www.yuzhnoye.com/ua/cp/kpo/sok/

Zakon Ukrayiny. Pro kosmichnu diyal'nist': vid 15.11.1996 r. Vidomosti Verkhovnoyi Rady Ukrayiny. № 1. - St. 2, 1997.

Zakon Ukrayiny. Pro vnesennya zmin do Zakonu Ukrayiny "Pro pidpryyemnytstvo" (stattya 4): vid 23.12.1997 r. Vidomosti Verkhovnoyi Rady Ukrayiny. № 17. — St.80, 1998.

Zakon Ukrayiny. Pro litsenzuvannya pevnykh vydiv hospodars'koyi diyal'nosti: vid 01.06.2000 r. https://zakon.rada.gov.ua/laws/show/1775-14/ed20080101

Zakon Ukrayiny. Pro vnesennya zmin do Zakonu Ukrayiny "Pro litsenzuvannya pevnykh vydiv hospodars'koyi diyal'nosti”: vid 25.06.2009 r. https://zakon.rada.gov.ua/laws/show/ $\mathrm{ru} / 1775-14$

Zakon Ukrayiny. Pro tekhnichni rehlamenty ta otsinku vidpovidnosti: vid 15.01.2015 r. Vidomosti Verkhovnoyi Rady. № 14. - Ст.96, 2015. 